サテライトシンポジウム 4

\title{
IL-2 の臨床応用の現状と展望
}

\author{
小倉剛
}

Jpn. J. Clin. Immun., 14 (5) : 569 570, 1991.

IL-2 は, アメリカと本邦でリコンビナント IL-2 が 相次いで開発されて基礎研究が一段と進展し，その主 な生物学的活性としては, TCGF 以外に, マクロフ アージ，NKやT細胞の活性化による腫場細胞障害活 性の増強, $\mathrm{B}$ 細胞の分化, 增殖への関与, $\mathrm{T}$ 細胞加 らの種々のサイトカインの産生誘導, マクロファージ などによる抗菌活性の発現などが明らかにされてき た。したがって, 免疫不全, 感染症, 癌などで臨床応 用が検討されている.

まず癌治療への応用面では，大量の IL-2 を連日な いし間歌的に患者に投与し，体内に活性化キラー (LAK) 細胞を誘導する方法が試みられた。 その結 果, 静注法では, 悪性血管内皮腫, 腎癌, メラノーマ である程度の奏効率が得られたほか, 癌性胸膜炎や膀 睄癌での胸腔内, 膀胱内注入, 頭頝部腫場への腫瘍内 注入などの局所的投与で奏効性が認められている.癌 患者末梢血りンパ球を in vitroで IL-2 と培養し誘導 した LAK 細胞とIL-2 による養子免疫療法も行われ， 腎癌,メラノーマ, 大腸癌などで IL-2 単独投与より は高い奏効率が得られている。しかし，奏効率を高め 臨床的有用性を上げるには，自家腫瘍細胞に高い障害 性を示す LAK 細胞が腫愓部位に選択的に局在するこ とが重要となるが,これまでの報告では，いずれも期 待されたほどの成䋶が得られていない．そこでこれら の欠点を補うべく腫瘍組織内浸潤リンパ球を前駆細胞 として同様な養子免疫療法が行われたが，手技，経済 面，副作用などを含めた臨床的有用性を考慮すると， まだ実用化されるには至っていないと思われるし，何 よりも癌告知が一般化していない本邦では, 患者を対 象にして試行錯誤的な治験を続けるには問題が多く， さらに基礎的な面での研究をより充実させる必要があ

徳島大学第 3 内科
るそここで教室では, 癌性胸膜炎に対するIL-2 の局 所投与例で胸水中のサイトカインの変動を解析し, $\mathrm{IL}-3,-4,-5,-6$, TNF $-\alpha$, IFN - $\gamma, \mathrm{M}-, \mathrm{GM}-$ $\mathrm{CSF}, \mathrm{TGF}-\beta$ などの上昇を認め, さらに, これらサ イトカインは in vitro での末梢血単核細胞からの LAK 誘導系に添加すると, 直接または単球機能への 影響を介して LAK 活性の誘導や, リンパ球の障害因 子であるパーホリンの誘導に調節的効果を及ほすすこと を見いだした。このようなサイトカインネットワーク を介した細胞間調節機構の解明は, 抗腫湟効果の向上 のみならず副作用の軽減の面でも重要な研究テーマで ある.

IL-2 と他の治療法の併用による抗腫場効果の向上 も重要な研究テーマである. サイトカインとの併用に 関しては, IFN $-\beta$, IFN $-\alpha 2$ a どとの併用が報告 されているが奏効率は低い. 教室の成績では, IFN$\alpha,-\beta$ は LAK 誘導を抑制する可能性があり, 投与方 法を検討する必要があろう。しかし，図1に示すよう にヒト腫瘍細胞株で TNF, IFN, LAK 細胞による 細胞障害活性に対する感受性を調べてみると，これら スペクトラムにかなりの差が認められる場合があるの で, 今後サイトカイン併用は魅力的な治療法の一つで ある. 化学療法剂との併用も検討されているが, IL2 や IL-2+LAK 養子免疫療法が奏効する腎癌やメラ ノ一マ, 大腸癌は元来化学療法に感受性が低く, 優れ た併用効果はみられていない.しかし in vitro でシス プラチンやアドリアマイシンに耐性を獲得させた癌細 胞は，親株に比べて著明に LAK 細胞に対する感受性 が上がる場合が発表されており，この方面も今後研究 すべき分野である。

すでに述べたように，いずれのエフェクタ一細胞に しろ, in vivoで腫湟縮小効果を上げるには腫瘍細胞 に接着することが必要である。この点, 最近発表され 


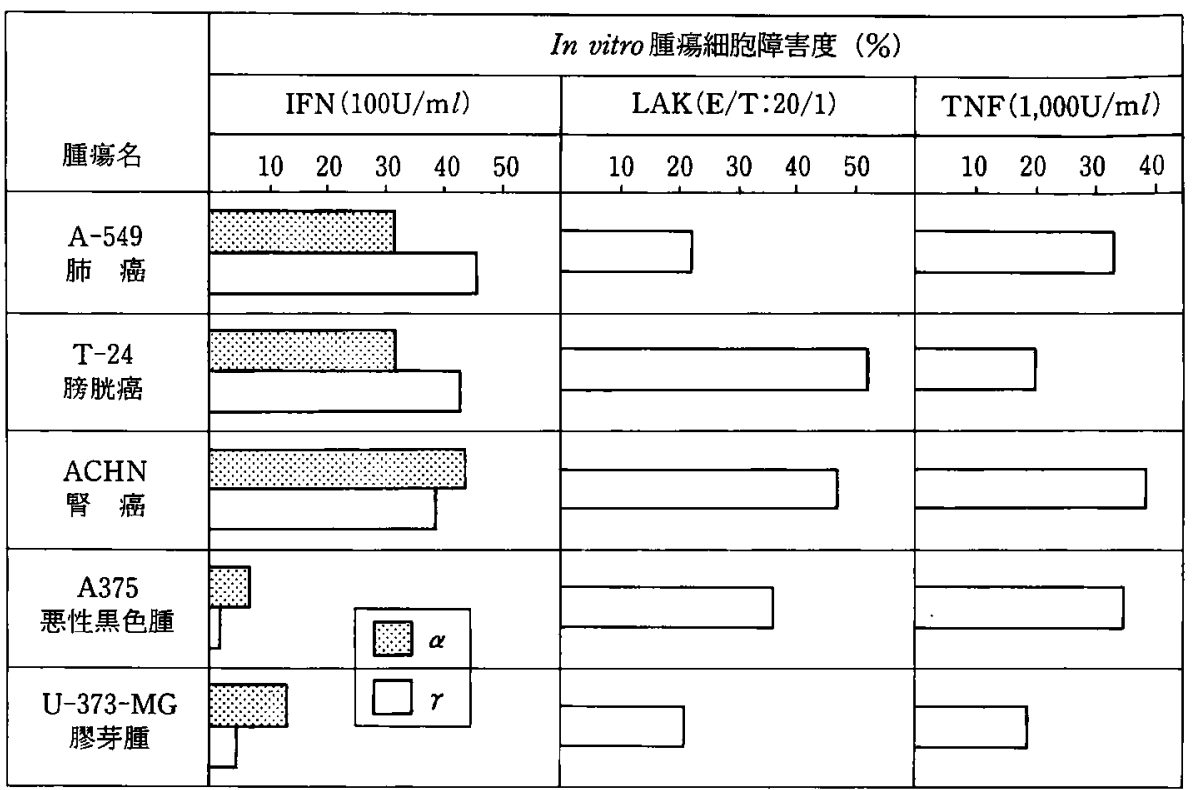

図 1 各種七卜腫瘍細胞株の IFN $(\alpha, \beta)$, TNF, LAK 細胞による障害度の比較 腫瑒細胞により障害が異なる。

た bispecific 抗体と LAK 細胞を脳グリオーマに局所 投与し，従来の治療法に比べて著しい腫瘍縮小効果と 生存期間の延長を認めた順天堂大のグループの成績は 大変臨床的に期待される成果である. 現在, 肺小細胞 癌に対しても研究が進行中である.

免疫不全症に対する IL-2 投与の効果は, 厚生省の 免疫不全症調查研究班によって発表されている。慢性 活性性 EBV 感染症, CVID などで有効例が報告され ているが，効果発現率がまだ低く，発現機序も十分明 らかでない.

B 型肝炎に対する IL-2 静注療法の効果も発表され ている. 1-4 週間の投与で HB 抗原陰性化と HBe 抗 体発現，すなわち seroconversion が検討されている が，IFN 療法による成績と比較して優れているとは いえず，併用を含めて今後の検討が必要であろう。

AIDS に対する IL-2 投与の効果も報告されたが, 現在までのところ有用性は認められていない。むしろ IFN- $\gamma$ との比較試験において, IFNではほとんど発 生しない感染症, とくに細菌性感染症が有意に多く発
生しているとの報告がある. 同様に，海外の文献で は，IL-2士LAK 療法に扔いて $19 \%$ に敗血症を発生 したとの成績や，末梢血幹細胞採取用にカテーテルを 入れた患者と IL-2 を投与するためにカテーテルを入 れている舶を比べると，有意に後者群で菌血症の発 現が高いとの成績が昨年と今年にそれぞれ報告されて いる. 原因として好中球遊走能の低下などが指摘され ているが，注意すべき点である。

以上, 簡単に IL-2 の臨床応用の現状について研究 が進んでいる癌治療面の成績を中心に問題点や今後の 研究の方向性を指摘しつつ概説した。 とくに癌に関し ては, Rosenberg一門による当初のみごとな成績に 引つ張られて研究, 臨床が発展してきたが, 現在のと ころ 2,3 の領域を除いて過大な期待への反省が高ま っているといってよい. しかし，この方面の研究は緒 についたばかりといってもよく，また自己の身体成分 を利用した治療法という点でも今後さらに基礎的, 臨 床的研究を充実させることが重要であろう。 